Canadian Journal of Higher Education Revue canadienne d'enseignement supérieur

Volume 46, No. 2, 2016, pages 127 - 147

\title{
Mapping Trends in Pedagogical Approaches and Learning Technologies: Perspectives from the Canadian, International, and Military Education Contexts
}

Grazia Scoppio

Royal Military College of Canada

Leigha Covell

Queen's University

\begin{abstract}
Increased technological advances, coupled with new learners' needs, have created new realities for higher education contexts. This study explored and mapped trends in pedagogical approaches and learning technologies in postsecondary education and identified how these innovations are affecting teaching and learning practices in higher education settings, particularly for the Canadian Armed Forces education system. A qualitative research methodology was employed including a comprehensive review of Canadian and international literature, an environmental scan of Canadian Armed Forces educational institutions, and consultations with experts and practitioners in the field of military education. The research findings shed light on trends in pedagogies and learning technologies in higher education as well as on the presence of these trends in the military educational system. In addition, the findings consider the necessity for a corresponding level of preparedness to meet the needs of diverse learners in the future. This study informs both the field of higher education and the field of military education.
\end{abstract}




\section{Résumé}

Associé aux nouveaux besoins des apprenants, le progrès technologique est à l'origine de nouvelles réalités dans le contexte de l'enseignement supérieur. Cette étude a relevé, puis analysé, les tendances des approches pédagogiques et des technologies d'apprentissage en matière d'enseignement supérieur, pour ensuite reconnaître les façons dont ces innovations influencent les pratiques d'enseignement et d'apprentissage dans des contextes d'enseignement supérieur, en particulier dans le système d'éducation des Forces armées canadiennes. Une approche qualitative a été utilisée pour effectuer un examen complet de la littérature canadienne et internationale, une analyse de l'environnement des établissements d'enseignement des Forces armées canadiennes, et des consultations avec des experts et praticiens dans le domaine de l'éducation militaire. Les résultats de la recherche éclairent sur les tendances en pédagogie et en technologies d'apprentissage dans le domaine de l'enseignement supérieur, ainsi que sur la présence de ces tendances dans le système d'éducation militaire. En outre, ces résultats examinent la nécessité de préparer de façon équivalente les Forces armées canadiennes à répondre aux besoins futurs de divers apprenants. Cette étude s'applique donc tant au domaine de l'enseignement supérieur qu'à celui de l'éducation militaire.

\section{Introduction}

For well over a century, adult learning has occurred formally in educational institutions and informally in other settings. However, in the last 60 years adult education has come to be viewed as an educational practice and discipline stemming from the quest for adult learners to develop skills and advance careers (Rubenson, 2010). More recently, technology has facilitated the ability to learn from nearly anywhere in the world through Internet access, which has enabled masses of adult learners to engage in educational opportunities, regardless of location, context, or background (Bakia, 2010; Hiltz \& Turoff, 2005; ICDE, 2009; Kanwar \& Daniel, 2010; Means \& Roschelle, 2010; Scott, 2010).

Along with technological advances, related learning technologies have also evolved, from simple forms of material distribution to more complex tools for communication, knowledge sharing, or forums. This rapid shifting of learning technologies raises the question of whether postsecondary education institutions are focused on keeping up with the changes rather than examining them for best practices and investigating the affect of these changes on instructors and learners.

This article summarizes a research study ${ }^{1}$ that addressed these key issues by mapping recent trends in pedagogical approaches and learning technologies, and exploring how these innovations are affecting teaching and learning practices in higher education, particularly in the context of Canadian military education and professional development. ${ }^{2}$ While the target audience of the research is a military audience, many of the findings are applicable to a broader audience in the higher education sector. This will help ensure the educational landscape evolves and innovates in order to meet the needs of diverse learners and prepare them for the future. 


\section{Methodology}

This paper summarizes a research study conducted from September 2013 to March 2014, carried out in two phases. The following primary research questions guided Phase I of the inquiry:

1. What are the recent trends in pedagogical approaches to postsecondary education?

2. What are the recent trends in learning technologies in postsecondary distance education?

3. How are these current pedagogical approaches and emergent technologies changing teaching and learning practices?

4. What are the current trends in military education?

Phase I involved a comprehensive search for relevant literature following predetermined procedures and topics that allowed for the systematic collection and management of documents, including reports, articles, and books written by academics or professional organizations known nationally or internationally within scholarly communities. The data collection process included domain definition and category construction based on research intentions. Key search terms such as "higher education trends," "trends in education," and "learning technologies" were entered into various online databases. Literature published within the past 10 years was prioritized and documents were sourced and collected from over 14 databases, including Academic Search Complete, British Education Index Portal, CBCA Education, Education Full Text (EBSCO), and Educational Resources Information Center (ERIC). A comprehensive review of relevant literature was completed, leading to document analysis to address the research questions through comparisons, trends, and patterns. This study focused on distance education delivered online (virtually) or through blended learning, that is, a combination of face-to-face interaction with online learning technologies (Singh, 2012).

Phase II of the study involved 11 consultations with 14 key Canadian experts and practitioners in the field of military education. The consultations were conducted following a convenience model and subsequently expanded using the snowball approach (McMillian \& Schumacher, 2010). They were conducted via email, phone, or in person (see Appendix A for a list of experts and Appendix B for the list of questions used in the consultations). Six of the consultations were in person, two by phone, and three by email. None of the face-to-face or phone consultations involved follow-ups, although the two email participants added a few clarifications. Following a qualitative analysis approach, the responses were thoroughly reviewed to create categories and highlight main themes (McMillan \& Schumacher, 2010).

Phase II involved an environmental scan of websites and documents related to selected learning institutions in the CAF: the Royal Military College of Canada, the Royal Military College St-Jean, the Canadian Forces College, the Army Command and Staff College, and the Canadian Defence Academy (now contained within Military Personnel Generation). The environmental scan included information publicly available to CAF learners anywhere, anytime.

This study was constrained by time and resources, which impacted the number of consultations in Phase II. The literature review was limited to publications in English, and most of the military literature discussed focuses on the Canadian viewpoint, although the scope of the literature review on 'civilian' education was much broader and included international perspectives. 


\section{Literature Review}

The results of the literature review are organized to first present emerging approaches, second to consider learners and educators, and third to focus on education in the military.

\section{Changes to Distance Education with the Emergence of Technology}

With the emergence of learning technologies, traditional paper-based courses were either supplemented by or evolved into other forms of learning defined as e-learning, online, or web-based learning. E-learning refers to the use of multimedia technologies and the Internet to improve the quality of learning by facilitating access to resources and services as well as exchanges and remote collaboration (European Commission, 2001). E-learning has resulted in more people accessing higher education and has subsequently influenced societies around the world (Means, \& Roschelle, 2010; Millwood, \& Terrell, 2005).

The discussion of specific Internet-based devices and their possibility to offer learning situations virtually anywhere has shifted to exploring the emerging web technologies that are used on such devices (Abik, Ajhoin \& Ensias, 2012; Saeed, Yang \& Sinnappan, 2009). Abrami, Bernard, Bures, Borokhovski and Tamim (2011) argue that as a result of the emerging technologies, "distance education and online learning have evolved beyond simple comparisons with classroom instruction" (p. 83). They contend that emerging technologies have the power to create interactions that are "guided, focused, and purposeful" and to enable learners to interact via technology in more complex ways through different forms of communication that use images, statements, or presentations, to name a few. (p. 88). Kearney, Schuck, Burden, and Aubusson (2012) have suggested that mobile learning can be viewed from a sociocultural perspective in which learning is affected and modified by the tools used for learning, which in turn influence the ways the tools are used. Evidence of this concept in practice can be seen in the boom in social networking that has spanned the globe. Research now links the use of social networking as a key element in knowledge construction (Singh, 2012).

\section{Blended Learning}

In line with the theory of social networking as a form of knowledge construction and the need for interaction among learners, are the concepts of blended learning or hybrid learning, which refer to learning that combines face-to-face classroom interaction with distance learning techniques to disseminate instructional materials and information (Singh, 2012). Blended learning can be used to provide a balance between virtual learning components with face-to-face interaction, thus increasing the likelihood for meaningful learning. However, it is important to ensure that pedagogical underpinnings (i.e. learning theory, instructional design, and the needs of the learners, etc.) are not overlooked in a blended learning environment (Hiltz \& Turoff, 2005; Turney, Robinson, \& Soutar, 2009).

\section{Open Learning}

Another trend that emerged in 2008 is that of Massively Open Online Courses (MOOCs) (Skiba, 2013; Howard, 2014). Originally based on connectivism and networking (Daniel, 2012), MOOCs are primarily characterized by the following criteria: they are 
delivered online, offer large enrolment, are open for participation with little to no cost to the students, and follow a course format with learning goals specific to an area of study (Educause, 2013). While sharing vast amounts of information and having a large student base is appealing for higher education institutions (Educause, 2013), MOOC learner persistence is of great concern. Researchers at the University of Edinburgh found that nearly $45 \%$ of learners who enrolled in MOOCs never became active learners in the online setting, with even fewer learners progressing through the course to obtain a statement of achievement indicating their learning (Woodgate, Macleod, Scott, \& Haywood, 2015).

\section{Learner Success}

Resta and Laferrière (2007) highlighted collaborative outcomes associated with technological developments and the importance of looking at product variable outcomes of collaborative learning, such as higher order thinking, deep understanding, and knowledge creation, which differ significantly from traditional theories and approaches to education. Online learning is also an avenue for encouraging continued professional development. By creating authentic and transformative learning experiences that allow students to manage their own learning, the students are more likely to continue their learning (Bozaleket al., 2013; Cleveland-Innes \& Emes, 2005; Lea \& Jones, 2011; Rezaei-zadeh, O’Reilly, Cleary, \& Murphy, 2011). In order to adopt the responsibility of designing and managing their own growth as a lifelong learner, a student should take on the role of an "independent, continuous, and active learner" (Cleveland-Innes \& Emes, 2005). Through creating a learning experience that is authentic and transformative, the student can make connections with knowledge that extend into multiple contexts and engage the student in critical reflection (Bozalek, et al., 2013; Wood \& Bilsborow, n.d.; Lea \& Jones, 2011; Cleveland-Innes \& Emes, 2005; Rezaei-Zadeh, et al., 2011; Schols, 2012). Ultimately, higher education curriculum should ensure the learner is an explicit component and have outcomes related to "knowledge and skill about learning and human development" (Cleveland-Innes \& Emes, 2005, p. 87).

The success of student learning hinges greatly upon many factors including but not limited to learning styles, learning needs, multiple intelligences, and the application of specific learning technologies and learner preferences (Crumpacker, 2001; Saeed, et al., 2009). Therefore, simple transmission of knowledge is no longer the only means to sustain ongoing professional development and the acquisition of new skills that are needed by today's ever-changing society (Bozalek, et al., 2013; Dearn, 2010; Schols, 2012).

\section{The Role of Educators}

To mitigate these diverse learners' needs, traditional instructors' roles are changing and educators need to develop relevant skills and require appropriate support to achieve current educational ideals (Howell, Williams, \& Lindsay, 2003; Taylor, 2000; Simelane, Blignaut, \& van Ryneveld, 2007; Misra, 2010; Wood \& Bilsborow, n.d.; Crumpacker, 2001; Renes \& Strange, 2011; Paulson, 2002; Dearn, 2010; Ryan \& Fraser, 2010). Educators should regularly consider the pedagogical potential of incorporating technology into their teaching. However, in the attempt to incorporate technology into their learning, some instructors feel overwhelmed, unprepared, and nervous about implementing the changes (Simelane, et al., 2007). 
Misra (2010) suggests that educators need to become E-excellent teachers who adapt technologies to suit their specific educational objectives and acquire teaching competencies that include an understanding that online education is not a tool but a "new context for learning." Critical to this process is the need for ongoing support for educators from governing authorities and institutions, and ongoing professional development that keeps the educator up-to-date with emerging technologies with a focus on the pedagogical applications (Kukulska-Hulme, 2011; Misra, 2010; Ryan \& Fraser, 2010). While students are in need of becoming lifelong learners, instructors require a sufficient understanding of pedagogical theories, regardless of the delivery methods (Kukulska-Hulme, 2011). Much like the way the most recent generation prefers interactive learning situations, so too are instructors more technologically savvy than previous generations.

The gap in technology ability between instructors is called "e-lag" (Mentis, 2008) and is defined as an impediment for educators to tailor their teaching approaches to current education contexts demanded by society (Rezaei-Zadeh, et al., 2011). Ultimately, educators should be "technologically skilled, schooled in various pedagogical approaches, and sufficiently anchored in the disciplines to be credible with mainline faculty" (Paulson, 2002, p. 137).

\section{The Role of Higher Education Institutions}

In considering the implications of emerging technologies on higher education, Singh (2012) states that, "higher education institutions, faced with the massification of knowledge production and the increased use of communication information technologies, have struggled to come to terms with the current changes" (p. 5). The continuous changes dictated by recent trends in higher education and distance education present challenges for higher education institutions as they have yet to be fully incorporated into policy and are creating gaps of variance in ability and use by instructors (Carter \& Graham, 2012). Organizations must undergo a process of "unlearning" in order to change habits, routines, and welcome the current pedagogy. White (2007) suggests that institutions have little "pockets" of excellence and that decision makers need to set up an institution-wide approach capitalizing on the way in which these "pockets" of individuals already function.

\section{Trends in Military Education}

Prior to exploring the implications of these trends and innovations in the military context, it is important to first define military education. While military (or defence) education was traditionally focused on skills acquisition, it has evolved in scope and purpose. According to Barrett (2007), the central purpose of military education is to lead to action with a "larger objective [of] seek[ing] increased global stability and security, unfettered by doctrine but informed by a shared ethical framework" (p. 40). Barrett continues by describing how working across the cultural divide between defence education and traditional academia adds further complexities; however, despite its uniqueness, defence education draws from all academic disciplines and must span an entire career. Cowan (2001) explains how the "complexity of thought and maturity of judgment" for military members are contingent upon a strong education that counters experience.

Although military education may have a unique purpose, it also responds to typical trends in education and must consider learning technologies and approaches in moving for- 
ward (Barrett \& Green, 2008). New demographics and generations are changing military service and thus changing education as a result (Carlson \& Andress, 2009). While the millennial generation first entered the military in the late 1990s, little is known about how the generational differences fully impact military education (Ender, Rohall, Matthew, 2014).

Cowan (2001) describes how for many years the CAF has offered a military education opportunity to all citizens regardless of socioeconomic status, and as a result, the CAF has been a major contender in attracting new members. Drawing in students from diverse backgrounds, creating a collective set of values, and instilling a common belief in teamwork over a four-year period of full-time education are factors that Cowan (2001) defines as unique to the CAF education system. Currently, however, other less costly, or even virtual, universities have increased competition. This has been mitigated through the development of distance learning components for both residential students and students from remote locations.

From a military perspective, changes in technology have greatly impacted traditional beliefs of a military members' role, and it is now critical to have a knowledge base that extends far beyond the task and considers the unique context locally, nationally, and internationally (Carlson \& Andress, 2009). Given the requirement for ongoing postings and deployments that result in working in remote locations, the ability to use technology in distance education has increased learning opportunities for military students, as well as the level of interaction among students and instructors. It has also created the opportunity to engage in higher level thinking on a frequent basis. Bernard (2005) states that it is imperative to abandon the "card punching" approach in the CAF where little learning beyond the specific job requirement is met, and to encourage and facilitate CAF member higher education.

The call for changes and necessity to respond to changes has a critical impact on the functionality of the organization (Bell, 1986; Bernard, 2005; Barrett \& Green, 2008; Barrett, 2009; Scoppio, 2003; Johnson-Freese, 2012; Foot, 2006). Ultimately, as stipulated by Barrett \& Green (2008) and Scoppio (2012), the CAF higher education system is under scrutiny and pressure to adapt to pedagogical trends and become a "learning organization" that creates meaningful learning situations for CAF members.

\section{Environmental Scan of CAF Educational Institutions}

Through the environmental scan conducted, three core educational institutions that provide common education to members of the CAF across three environments-land, sea, and air-were identified, namely: the Royal Military College of Canada (RMCC) in Kingston, Ontario; the Royal Military College Saint-Jean (RMC Saint-Jean) in Saint-Jean-surRichelieu, Quebec; and the Canadian Forces College (CFC) in Toronto, Ontario. Several other organizations or 'schools' also provide education, training, and professional development (such as specific environmental training, military occupational training, language instruction) to select groups and members.

To prepare officers and non-commissioned members (NCMs) with the critical knowledge and skills to best counter an ever-changing global theatre, the CAF has developed a professional development system that integrates training, education, self-development, and experience. The professional development system provides a continuous learning environment through sequential development periods in order to enhance leadership ca- 
pabilities and foster the specific skills, knowledge, and attitudes needed throughout CAF members' career (Government of Canada, National Defence and the Canadian Armed Forces, 2015a). The foundation of military professional development is provided by military doctrine, defined as: "[f]undamental principles by which military forces guide their actions in support of objectives" (North Atlantic Treaty Organization, 2008). These continuing education and training opportunities are founded on the principle that lifelong learning is a core element of modern militaries.

Created in 2002 and contained within Military Personnel Generation (MILPERSGEN) as of June 3, 2015, the Canadian Defence Academy is the organization that ensures the CAF Professional Development System remains relevant and resilient (Government of Canada, National Defence and the Canadian Armed Forces, 2015b). RMCC, RMC SaintJean, and CFC all fall under MILPERSGEN Command and are examples of CAF institutions offering military education by combining residential onsite educational programs with off-site programs, offered through virtual learning environments to provide learning opportunities to CAF members regardless of time zone or location. The environmental scan of websites revealed information regarding institutional missions, academic programs, professional development and training programs; however, there was little information about learning theories, trends, learning approaches, or the role of learning technology in military education, beyond identifying that distance education offered by some CAF education institutions uses online learning management systems. Ultimately, MILPERSGEN was the only institution, among those explored through the environmental scan, that held publicly available documents describing the changing role of technology in CAF education. It is possible that information on learning approaches adopted may be contained in internal documents within each institution, for the specific use of educators rather than students.

MILPERSGEN prepares officers and NCMs with common training and the education needed for modern-day complex missions. It oversees the CAF Individual Training and Education System (IT\&E) and is involved with other training and education management authorities in the CAF. The system is designed to foster the appropriate level of training and education needed from the moment an officer or an NCM joins the CAF to when they leave. For example, in 2012 MILPERSGEN (at the time called Canadian Defence Academy, CDA) and its formation units provided professional development for nearly 40,000 trainees and offered several hundred courses. In the last few years, the initial call for an examination of the changes required to the existing IT\&E System was re-envisioned and through IT\&E Modernization and a pan-CAF collaboration led by MILPERSGEN, gaps, inefficiencies, and solutions were identified in order to modernize the system and maintain a competitive edge in the international theatre. The outcome of the collaboration is CAF Campus, which is a "synchronized performance oriented learning architecture that supports the transformation of the CAF learning culture for the $21^{\text {st }}$ century" (Government of Canada, National Defence and the Canadian Armed Forces, 2013). Key projects identified as components of modernization include Learning Support Centres; CAF Campus Enterprise Engine, a digital learning network that provides constant access to learning; Performance Management Framework, a tool used as quality assurance for CAF Campus and related programmes; and Common Capabilities, tools used to support the appropriate application of particular supports. The Defence Learning Network, the 
corporate, online learning-management platform used across defence, is also part of the CAF Campus architecture (Government of Canada, National Defence and the Canadian Armed Forces, 2015c).

\section{Consultations}

Following the environmental scan, the analysis of the consultations led to the identification of themes, that is, topics or issues that were highlighted by more than one participant. Fifteen key themes were identified:

- the need to commit to the ideal of lifelong learning

- need for new pedagogies

- a gap in pedagogical foundation

- little recognition of the value of pedagogy

- mixed feelings by educators about learning technologies

- examples of learning technologies currently in use

- a lack of awareness of learning technologies in CAF

- the need for technology to create networks

- lack of support for educators and their reluctance to change approach

- a lack of direction for the adoption of new technologies

- acknowledging the changing roles for instructors and students

- poor preparation for educating diverse learners

- acknowledging the importance of the new generation of learners

- need for human and financial resources to support educators in adopting new technologies

- the need for an awareness of the differences between education versus training

For the purpose of this article, it is not possible to address each theme at length. Hence, the focus is on key themes that appear the most relevant to the military education context and to the broader higher education community. The significant findings stemming from the key themes are summarized in the following sections.

\section{Recent Pedagogies and Learning Technology Integration}

Many of the key experts highlighted the existence of a wide spectrum of learning technologies and changes in CAF education settings. One expert said, "[we] haven't been doing standard brick-and-mortar classroom [structure] in a long time" (Consultation 3). Another expert stated

If new means the use of IT for curriculum delivery, then I have to say that [we] use a blended delivery format and there are certain technologies used in the classroom. At RMCC, the Continuing Studies Division has employed various ways for getting course materials and classes to students ... Moodle ${ }^{3}$ [has been used] most recently. (Consultation 1)

For another expert using simulators for decision-based gaming scenarios facilitates "better learning due to [use of] repetitive skills but also [contributes to] more complex learning" (Consultation 5). The expert from Consultation 4 described how "there are 29 different items [in the CAF Campus documents] that are moving forward concurrently, 
including partnerships, changes to doctrines, performance improvement systems, and a blended learning working group."

\section{Responding to the Needs of Recent and Future Learners}

The critical role of the instructor and student in the processes was central to many comments regarding the presence of learning technologies or pedagogical approaches. One expert described

the new generation [of learners] coming in [as] hav[ing] expectations ... they are coming from an environment with a lot of technology so we can't just use the 'chalk and talk' [approach] ... [we] have to up [our] game. (Consultation 6)

Consultation 8 suggested that before the students arrive there is a need to "calibrate and map the learning abilities of the students." Consultation 3 suggested that "we, as a collective, need to assess the needs of the community to identify [students'] needs as opposed to telling them what [the needs] should be." Consultation 6 felt that Simply using technology without considering other pedagogical approaches puts the learning at risk by potentially "marginalizing some of the students."

Many of the key experts expressed an institutional lack of support for the adoption of learning technologies and pedagogical approaches to assist the diverse learners who have enrolled in CAF education. The key experts indicated the, importance of offering a meaningful CAF education that encourages a desire for lifelong learning. One expert noted that "the old approach ... didn't want soldiers to be smart. Now our soldiers need to turn wrenches and fire rifles, but [they] also need to think" (Consultation 3). There is a need to move "away from the concept that learning is an event ... learning is a continuum within that domain" (Consultation 4). Ultimately, "learners have changed but our educational system hasn't, and I don't see any educational guidelines that we can use for change" (Consultation 8). Finally, another expert revealed the following concerns:

The CAF Campus concept has been there for about 5 years, but in those 5 years, I am not sure how much change has occurred. I am not sure that we will be prepared for the sets of learners to provide an instructional environment suited to their needs. (Consultation 3)

\section{Gap in Pedagogical Foundation}

To further complicate the issue, the key experts consulted noted the presence of learning technologies without consideration for pedagogical benefits (Consultations 5 and 11). One participant described the perceived reluctance of some instructors to change their teaching practice and how "none, other than by coincidence, had any qualifications in education [i.e. the theory and practice of teaching]" (Consultation 1).

Given that the CAF education system serves multiple purposes, the experts outlined how outcomes must be directly linked with the specific form of education within CAF institutions. Another expert described how there is a need to "reframe education to provide skills and tools for excellence through the use of technology" (Consultation 4). One expert described how 
education is different; we have to make sure that the people implementing the CAF campus understand the nuances between training and education ... it is important that they [i.e. the leadership in the administration]come down with the concept, but we [i.e. the educators] need to be consulted regarding what kind of product [i.e. learning technology] we need. (Consultation 2)

Another expert stated that the problem will persist "unless we can explain to both ourselves and to decision makers why we need competencies for the academy then we risk not getting what we [CAF] need, or indeed not getting anything" (Consultation 1). Another expert predicts that the CAF education and professional development system will adapt to the different learning approaches but "not as quickly as the rest of the education 'world"' (Consultation 5).

\section{Lack of Support and Reluctance to Change}

The lack of instructor support and a perceived reluctance to change also contribute to the limited or inappropriate presence of learning technologies and consideration of pedagogical approaches. One expert suggested that evidence for a reluctance to change could be seen in the absence of technology in the classrooms: "there are a lot of non-believers . . . many professors think that nothing replaces the cours magistral and don't even want to try it [technology]" (Consultation 9). Contributing to this reluctance is the lack of institutional guidelines so "at the moment [we] go with the flow. Some individuals are adapting to the changes, but it is not an orchestrated, organized way of dealing with these changes" (Consultation 8). Consultation 7 said that because "the CAF has not been very focused on new learning technologies ... we as a school, as an independent entity, will venture into distance learning and experiment on our own, similar to other schools" (Consultation 7).

Another expert described how "learning technology allows for interacting that can be more reflective of and allow for more people to participate, in a way that some people may not be as comfortable [with] in the classroom" (Consultation 1). Consultation 2 felt that "learning technologies have to be connected and networked [creating] a network of a community of peers, connected through the Internet." This expert also described how a Defence Learning Network (DLN) "set to provide a common learning platform ... instead ... has provided a common set of restraints" (Consultation 3). Consultation 10 described how the "issue is to establish what it is we want to use the technology for, we should be using technology to improve learning and not just using it for the sake of using it." Another expert described how "too often "new' is equated with better and this is not always the case" (Consultation 11).

Dominating the discussion regarding the factors and strategies for incorporation of new learning technologies and pedagogical approaches is the requirement for support by way of resources. One expert commented on the need for "attitudinal buy-in from professors and instructors," and resources, with the next step being "time for faculty" to become familiar with "concepts of education and with associated concepts and practices for using technology in learning programmes" (Consultation 1). Another expert detailed how they [i.e. the educators] do not see the "IT [information technology] infrastructure [as] being flexible enough to adapt to the individual learning styles" (Consultation 10). 


\section{Discussion}

This section will provide a combined analysis and discussion of the key findings of the research conducted, by integrating the literature review, the environmental scan, and the consultations. Overall, the study illustrates the complexity of the higher education landscape faced by educational stakeholders within the CAF context. The recent past of higher education has witnessed remarkable changes across multiple contexts and aspects of the discipline; these changes have created dramatic reconsiderations of traditional educational techniques and approaches. Some of the trends that emerged in postsecondary education in the recent past include but are not limited to technological changes, different pedagogical approaches, and open learning. The profile of learners and educators is also changing, and so a wide spectrum of technological ability can be found between both groups. The military education system is not immune to these trends. Hence, change is occurring both at the broader organizational level, through system-wide initiatives such as the CAF Campus, and at the school level, for example in the RMCC or the Canadian Army Command and Staff College. Overall, the traditional "brick and mortar" approach is being supplemented by learning technology. At the same time, strategic decisions at the organizational level do not always translate in a clear vision, coherent implementation plans, or appropriate resources and support for the educational institutions and their instructors.

Based on the issues presented in the previous section, it is clear there is a pressing need for mapping the way forward. As such, the following are three key areas of higher education that should be considered by CAF and other education stakeholders to enhance their education and professional development system.

\section{Focus on the Pedagogy}

The importance of sound pedagogical foundations should not be undermined by the constant changes in learning technology. During the boom of modern learning technologies in the late 1990 s and early 2000 s, the demise of distance education was predicted as a result of the influx of changes (Tulloch, 2000); however, this prediction has yet to be realized, and it could be argued that the opposite has occurred. Kirkwood and Price (2013) believe that developing a more pedagogically grounded scholarly approach among educators versus a technology-led approach will maximize the effectiveness of the discipline rather than struggling to constantly keep up with the changes.

Moreover, the variance in consideration and use of learning technologies and approaches means that not all students are receiving equal education opportunities. Recognition of the need for a strategically competitive higher education setting has been outlined, yet the way to achieving such a standard is left unaltered. Blended learning is presented as one possible option to maintain particular directives and enhance or change others.

\section{Critically Evaluate Learning Technologies}

Anderson \& Dron (2011) suggest a paradigm is emerging in distance education that is characterized by an increasing desire for privacy, which will impact the networks in which we belong and the movement towards more object-based, contextual, or activitybased models of learning. Prior to instantly adopting a learning technology to be used in 
higher education, the technology should undergo a process of review to critically assess it for pedagogical appropriateness and relevance to the new generation of learners and the specific learning objectives.

\section{Strong Support for Instructors}

The findings of this research study indicate a varied landscape of ability and use of learning technology. This gap must be addressed in order to successfully implement any system-wide changes; suggestions for support in terms of additional training, both pedagogically and technologically, coupled with standards of practice and institutional accountability would assist in mitigating any problems that may arise.

\section{Conclusion}

This article summarized the findings of a qualitative study that was conducted as an initial mapping of the higher education landscape in order to inform the way ahead for some CAF educational institutions and potentially some civilian educational institutions. After the initial comprehensive report ${ }^{4}$ was distributed within the defence education and research community, positive feedback was received, and it is hoped that this will spark further research in this domain.

The research highlighted some of the recent trends in postsecondary education, many of which are common to both the civilian and military education sectors. While learning technologies are increasingly embraced by both military and civilian educational institutions, there are some challenges. One of the challenges identified is the difficulty in keeping up with the pace of change of these technological innovations. This poses difficulties for researchers, educators, and higher education institutions attempting to make sense of it all. The study further identified that the learning technologies adopted are not always well grounded in pedagogical foundations.

The study also underscored the importance of education not being seen as a single event but as an ongoing engagement. The notion of lifelong, self-guided learning as an outcome will remain a strong consideration for the evolution of new technologies in years to come (Parsons, 2010; Anderson, Boyles, \& Rainie, 2012). Further, the increase of learning networks and open learning (MOOCs), which allow groups of individuals to assist in guiding each other's learning (Anderson \& Dron, 2011), appear to be approaches that will continue to expand.

Finally, the continued external presence of unlimited, free learning facilitated by modern technology indicates the changing role of higher education institutions, where the transmission of knowledge need not necessarily be linked with institutions, and certainly not with "brick and mortar" schools. However, the value of higher education and of postsecondary institutions in providing lifelong learning opportunities to develop critical thinking, creativity, analytical thinking and problem-solving skills will likely remain unchanged for the foreseeable future.

In this evolving educational landscape of ever-changing learning technologies, virtual learning, and open learning, the role of institutional leaders has to be to articulate a clear vision and provide appropriate resources and supports in order to successfully implement educational transformation and modernization. Instructors will need to become 
"e-excellent" teachers and also to understand pedagogical underpinnings of contemporary higher education in order to provide meaningful learning experiences to "new" and "older" learners, as they embark on the path of lifelong learning.

\section{Notes}

1 This research study was conducted as part of a larger project "Harnessing $21^{\text {st }}$ Century Skills" funded through a Technology and Innovation Fund (TIF) under Partnership Group 4 (Personnel), sponsored by Defence Research and Development Canada and Director General Military Personnel Research and Analysis, Department of National Defence. The overall project was led by Professor Alan Okros, Deputy Chair, Department of Command, Leadership and Management, Canadian Forces College, Toronto, Ontario.

2 The Canadian Armed Forces Professional Development System is composed of four pillars: education, training, employment experience, and self-development. See Government of Canada, National Defence and the Canadian Armed Forces, Canadian Armed Forces Professional Development, 2015, retrieved from http://www.forces. gc.ca/en/training-prof-dev/index.page

3 Moodle is an open source learning platform; the name stands for Modular Object-Oriented Dynamic Learning Environment. More information is available on the official Moodle site https://moodle.org/

4 The technical report is an internal document of the Department of National Defence and is available by contacting the authors of this article.

\section{Acknowledgments}

This research study was sponsored by Defence Research and Development Canada and Director General Military Personnel Research and Analysis, Department of National Defence, as part of a larger project "Harnessing $21^{\text {st }}$ Century Skills," led by Professor Alan Okros, deputy chair, Department of Command, Leadership and Management, Canadian Forces College, Toronto.

\section{References}

Abik, M., Ajhoun, R., \& Ensias, L. (2012). Impact of technological advancement on pedagogy. Turkish Online Journal of Distance Education, 13(1), 224-237.

Abrami, P. C., Bernard, R. M., Bures, E. M., Borokhovski, E., \& Tamim, R. M. (2011). Interaction in distance education and online learning: using evidence and theory to improve practice. Journal of Computing in Higher Education, 23, 82-103. DOI 10.1007/ S12528-011-9043-x

Anderson, J. Q., Boyles, J. L., \& Rainie, L. (2012). The future impact of the Internet on higher education: Experts expect more-efficient collaborative environments and new grading schemes; they worry about massive online courses, the shift away from oncampus life. Pew Research Center, Washington.

Anderson, T., \& Dron, J. (2011). Three generations of distance education pedagogy. The International Review of Research in Open and Distance Learning, 12(3), 80-97. 
Bakia, M. (2010). Technology and learning-global trends: Internet-based education. International Encyclopedia of Education, 102-108.

Barrett, A. J. (2007). Defense education curriculum: How to ensure it produces the right results for PfP members? Proceedings of the Ninth Annual Partnership for Peace Consortium Conference, Zagreb, Croatia; Syndicate 1, 35.

Barrett, A. J. (2009). Modern developments in defense education. Connections Quarterly Journal, 8(2), 1-5.

Barrett, A. J., \& Green, D. E. (2008). The CF IT\&E system is overdue for change. Canadian Military Journal, 9(1), 98-99.

Bell, J. (1986). Professional military education: Tasks, topics, needs. Armed Forces and Society, 12(3), 419-430.

Bernard, S. (2005). Educating officers for the 21st century: Card punching or profession of arms? Canadian Army Journal, 8(4), 50-64.

Bozalek, V., Gachago, D., Alexander, L., Watters, K., Wood, D., Ivala, E., \& Herrington, J. (2013). The use of emerging technologies for authentic learning: A South African study in higher education. British Journal of Educational Technology, 44(4), 629-638.

Carter, L., \& Graham, R. D. (2012). The evolution of online education at a small northern Ontario university: Theory and practice. The Journal of Distance Education, 26(2).

Carlson, E., \& Andress, J. (2009). Military service by twentieth-century generations of American men. Armed Forces and Society, 35(2), 385-400.

Cleveland-Innes, M., \& Emes, C. (2005). Principles of learner-centered curriculum: Responding to the call for change in higher education. The Canadian Journal of Higher Education, 35(4), 85-110.

Cowan, J. S. (2001). RMC and the profession of arms: Looking ahead at Canada's military university. Canadian Military Journal, 2(3), 5-12.

Crumpacker, N. (2001). Faculty pedagogical approach, skill, and motivation in today's distance education milieu. Online Journal of Distance Learning and Administration, 4(4).

Daniel, J. (2012). Making sense of MOOCs: Musings in a maze of myth, paradox, and possibility. Journal of Interactive Media in Education, 18, 1-20.

Dearn, J. M. (2010). Innovation in teaching and curriculum design. International Encyclopedia of Education, 448-454.

Ender, M. G., Rohall, D. E., \& Matthews, M. D. (2014). The millennial generation and national defense: Attitudes of future military and civilian leaders. New York, NY: Palgrave Macmillan.

Educause (2013). 7 things you should know about MOOCs II. Educause learning initiative. Retrieved from http://www.educause.edu/library/resources/7-things-youshould-know-about-moocs-ii

European Commission. (2001). Communication from the commission to the council and the European parliament: The e-Learning action plan. Designing tomorrow's education, Brussels, 28.3. $\mathrm{COM}(2001) 172$ final 
Foot, P. (2006). Military education and the transformation of the Canadian Forces. Canadian Military Journal, 7(1), 13-20.

Government of Canada, National Defence and the Canadian Armed Forces. (2013). CAF Campus: Operational Framework. Canadian Defence Academy: Kingston.

Government of Canada, National Defence and the Canadian Armed Forces. (2015a). Canadian Armed Forces professional development. Education and training in the Canadian Armed Forces. Retrieved from http://www.forces.gc.ca/en/training-prof-dev/ index.page

Government of Canada, National Defence and the Canadian Armed Forces. (2015b). Military personnel generation (MILPERSGEN). Retrieved from http://www.forces.gc.ca/ en/training-prof-dev/military-personnel-generation.page

Government of Canada, National Defence and the Canadian Armed Forces. (2015c). ALN/RAD. Retrieved from http://www.forces.gc.ca/en/training-elearning/dln.page

Hiltz, S. R., \& Turoff, M. (2005). Education goes digital: The evolution of online learning and the revolution in higher education. Communications of the ACM, 48(10), $59-64$.

Howard, K. (2014). Massive open online courses (MOOCs): Implications and opportunities for the community college system in New Brunswick. Post-Secondary Education, Training and Labour, Government of New Brunswick.

Howell, S. L., Williams, P. B., \& Lindsay, N. K. (2003). Thirty-two trends affecting distance education: An informed foundation for strategic planning. Online Journal of Distance Learning Administration, 6(3).

ICDE (International Council for Open and Distance Education). (2009). Global trends in higher education, adult and distance learning. Oslo, Norway: The International Council for Open and Distance Education.

Johnson-Freese, J. (2012). The reform of military education: Twenty-five years later. ORBIS, 135-153.

Kanwar A., \& Daniel, J. (2010). Higher education-teaching and learning in higher education: Distance education and open universities. International Encyclopedia of Education, 404-410.

Kearney, M., Schuck, S., Burden, K., \& Aubusson, P. (2012). Viewing mobile learning from a pedagogical perspective. Research in Learning Technology, 20, 1-17.

Kirkwood, A., \& Price, L. (2013). Missing: Evidence of a scholarly approach to teaching and learning with technology in higher education. Teaching in Higher Education, 18(3), 327-337.

Kukulska-Hulme, A. (2011). How should the higher education workforce adapt to advancements in technology for teaching and learning? Internet and Higher Education, $15,247-254$.

Lea, M. R., \& Jones, S. (2011). Digital literacies in higher education: Exploring textual and technological practice. Studies in Higher Education, 36(4), 377-393. 
McMillan, J., \& Schumacher, S. (2010). Research in education: Evidence-based inquiry (7th ed.). Boston, MA: Pearson.

Means, B., \& Roschelle, J. (2010). Technology and learning: An overview of technology and learning. International Encyclopedia of Education, 1-10.

Mentis, M. (2008). Navigating the e-learning terrain: Aligning technology, pedagogy and context. The Electronic Journal of e-Learning, 6(3), 217-226.

Millwood, R., \& Terrell, I. (2005). Overview: New technology, learning and assessment in higher education. Innovations in Education and Teaching International, 42(3), 195-204.

Misra, P. K. (2010). Preparing e-excellent teachers for the world of e-education: Potential strategies. I-Managers Journal of Educational Technology, 7(3), 21-29.

North Atlantic Treaty Organization. (2008). NATO Glossary of Terms and Definitions - AAP-6(2008). Retrieved from http://fas.org/irp/doddir/other/nato2008.pdf

Parsons, J. (2010). Envisioning education in the year 2050: By mid-century, what will education look like? Alberta Teachers' Association Magazine, 90(4), 30-35.

Paulson, K. (2002). Reconfiguring faculty roles for virtual settings. The Journal of Higher Education, 73(1), 123-140. DOI: 10.1353/jhe.2002.0010

Renes, S. L., \& Strange, A. T. (2011). Using technology to enhance higher education. Innovations in Higher Education, 36, 203-213. DOI: 10.1007/s10755-010-9167-3

Rezaei-zadeh, M., O’Reilly, J., Cleary, B., \& Murphy, E. (2011). A review of the bases and solutions to deficiency in the effective use of technology in the creation of lifelong learning in higher education. The 7 th International Scientific Conference eLearning and Software for Education, Bucharest, Hungary, April 28-29.

Resta, P., \& Laferriere, T. (2007). Technology in support of collaborative learning. Education Psychology Review, 19, 65-83. DOI 10.1007/s10648-007-9042-7

Rubenson, K. (2010). Adult education overview. International Encyclopedia of Education, 1-11.

Ryan, Y., \& Fraser, K.(2010). Education developmentin higher education.International Encyclopedia of Education, 411-418.

Saeed, N., Yang, Y., \& Sinnappan, S. (2009). Emerging web technologies in higher education: A case of incorporating blogs, podcasts and social bookmarks in a web programming course based on students' learning styles and technology preferences. Educational Technology \& Society, 12(4), 98-109.

Schols, M. (2012). Examining and understanding transformative learning to foster technology professional development in higher education. International Journal of Emerging technologies in Learning, 7(1), 42-49.

Scoppio, G. (2003). Change in the era of globalization: Implications for education and training in civil and military systems. Connections - The Quarterly Journal, No. 2, 69-79.

Scoppio, G. (2012). Lessons from the past to inform the future of military education: The first 10 years of the Canadian Defence Academy 2002-2012. Paper presented at the conference of the International Society of Military Sciences. Kingston, ON: Royal Military College of Canada. 
Scoppio, G., \& Tregunna, L. (2015). Mapping the Pedagogical Landscape in the 21st Century: Trends in Higher Education, the Role of Technology, and Implications for Canada's Military. Technical Report. Study sponsored by Defence Research and Development Canada.

Scott, P. (2010). Higher Education: An Overview. International Encyclopedia of Education, 1-11.

Simelane, S., Blignaut, S., \& van Ryneveld, L. (2007). Preparing lecturers to integrate educational technology into their teaching and learning practices. South African Journal of Higher Education, 21(7), 940-953.

Singh, R., J. (2012). Current trends in higher education learning and teaching. South African Journal of Higher Education, 26(1), 5-9.

Skiba, D. J. (2013). On the horizon: The year of the MOOCs. Nursing Education Perspectives, 34(2), 136-137.

Taylor, P. G. (2000). Changing expectations: Preparing students for flexible learning. International Journal for Academic Development, 5(2), 108-115.

Tulloch, J. B. (2000). Sophisticated technology offers higher education options. Technological Horizons in Education, 28(4).

Turney, C. S. M., Robinson, D., \& Soutar A. (2009). Using technology to direct learning in higher education. Active Learning in Higher Education, 1O(1), 71-83. DOI 10.1177/1469787408100196

White, S. (2007). Critical success factors for e-learning and institutional change-some organizational perspectives on campus-wide e-learning. British Journal of Educational Technology, 38(5), 840-850.

Wood, D., Bilsborow, C. (n.d.). Enhancing creative problem solving in the higher education curriculum through the use of innovative e-learning technologies. Proceedings from the International Conference on e-Learning, 416-424.

Woodgate, A., Macleod, H., Scott, A. M., \& Haywood, J. (2015). Differences in online study behaviour between sub-populations of MOOC learners. Educación XX1, 18(2), 147-163, doi: 10.5944/educXX1.13461

\section{Contact Information}

Grazia Scoppio

Royal Military College of Canada

Scoppio-g@rmc.ca

Grazia Scoppio holds a Ph.D. from the University of Toronto. She is an associate professor at the Royal Military College of Canada, in Kingston, ON, where she teaches in the Department of Defence Studies, while also serving as associate dean, Division of Continuing Studies. She currently teaches online courses on leadership and supervises Master of Defence Studies students. She is the author of a book, and author or co-author of 20 reports. Her interdisciplinary research appears in several edited books and journals. She 
presented at over 40 national and international conferences, and is an active member of various academic societies. She is the Editor (French) of the journal Comparative and International Education, jointly with the Editor (English) Dr. Marianne Larsen, Western University.

Leigha Covell, M.Ed., is an instructional designer for the Faculty of Engineering at Queen's University. In this role, she works one-on-one with faculty members to create and modify online and blended learning courses. She holds a Bachelor of Education, specializing in kindergarten and elementary education from McGill University and is a recent graduate of the Faculty of Education at Queen's University. She is now working towards a PostBaccalaureate Diploma in Instructional Design from Athabasca University. She has been actively involved in a number of research teams investigating new and beginning teachers and the role of technology in higher education.

\section{Appendix A}

\section{List of Experts in Alphabetical Order}

\section{Dr. Jim Barrett}

Dr. Barrett is a well-published scholar who has specialized in education management. He was Director of Learning Innovation for CDA and was former dean of Continuing Studies, RMCC. He is now a Professor Emeritus of RMCC.

\section{Lieutenant-Colonel Sylvain Beausejour}

Since graduating from RMCC and RMC Saint-Jean, Lieutenant-Colonel Beausejour has held a number of important positions within the CAF. At the time of the study, he was serving as associate vice-principal (Academic) at RMCC.

\section{Major Robert Breault}

Major Breault has served for many years with the CAF. At the time of the study, he was serving as the Chief Standards Officer for the Canadian Army Command and Staff College in Kingston, Ontario.

\section{Colonel Dalton Cote}

Colonel Cote joined the CAF in the early 1980 os and has held an active role in various aspects of training and development for the CAF. At the time of the study, he was serving as the Director of Individual Training and Education, CDA.

\section{Dr. John Cowan}

Dr. Cowan has a long history with university settings, serving as Senior Advisor on Labour Relations for the Association of Universities and Colleges of Canada. Dr. Cowan was the Vice-Principal (Operations and Finance) for Queen's University, the Chair of the Defence Science Advisory Board of Canada, and the former Principal of RMCC. He is now Principal Emeritus of the RMCC. 


\section{Dr. Allan English}

Dr. English is a nationally renowned scholar and Professor of Canadian military history. He served with the CAF for 25 years in a variety of positions. He has extensive experience as a former Associate Professor for RMCC and is currently an associate professor at Queen's University in Kingston, Ontario.

\section{Captain Pamela Holtz}

Captain Pamela Holtz has held positions in education within several units of the CAF over her career, including areas of training and development at CDA. At the time of the study, she was serving as the College Training Development Officer, Canadian Army Command and Staff College.

\section{Dr. Harry Kowal}

Dr. Kowal has taken on the role of the current Principal of RMCC after distinguishing himself academically and in the CAF setting both nationally and internationally. Dr. Kowal is a retired Brigadier-General with more than 33 years of service in the CAF.

Lieutenant-General (retired) Michel Maisonneuve - Lieutenant-General (retd) Maisonneuve assumed the position of Academic Director of RMC Saint-Jean after a distinguished history with the CAF. He has worked with organizations on an international scale and has held several high-profile positions in various areas within CAF.

\section{Major Len Matiowsky}

Maj Matiowsky is an experienced training development specialist who has been involved in a number of projects nationally and internationally. He has held a number of positions at CDA and at the time of the study, he was serving as Deputy Chief of Curriculum, Canadian Army Command and Staff College.

\section{Lieutenant-Colonel Scott Morrison}

Lieutenant-Colonel Morrison was formerly the Chief Curriculum Development at Security for the Department of National Defence. At the time of the study, he was serving as the Chief of Curriculum Development at the Canadian Army Command and Staff College.

\section{Dr. Pierre Roberge}

Dr. Roberge is a distinguished scientist, engineer, professor, and advisor in the area of science and engineering. He currently serves as the Dean of Division of Continuing Studies, RMCC.

\section{Dr. Craig Stone}

Dr. Stone accepted an academic position at CFC in 2005, after many years with the $\mathrm{CAF}$ in multiple roles. He has research interests in professional military education. At the time of the study, he was serving as the Director of Academics for CFC. 


\section{Dr. Randy Wakelam}

Dr. Wakelam has had an extensive military career involving a number of important academic positions. He was the former Director of Curriculum for the CFC, and the former Director of Professional Development for CDA. Dr. Wakelam is currently an Associate Professor at RMCC. 